\title{
フェオホルバイド $\mathrm{a}$ 投与ラットの光照射による中毒発現と 血液成分の変動
}

(昭和 57 年 5 月 10 日受理)

\begin{tabular}{|c|c|c|c|}
\hline & 斎藤由美子*1 & 石 田 博 子*1 & 関 洋 二*2 \\
\hline 三木 和 保*2 & 富金原 孝*2 & 河 原 裕 憲*3 & 伊 藤 \\
\hline
\end{tabular}

\section{Toxic Effects and Changes of Blood Components by Photodynamic Action Induced by Pheophorbide-a in Rats.}

\author{
Eiichi MatuURA ${ }^{* 1, * 4}$, Yumiko SAITO*1, Hiroko ISHIDA*1, \\ Yoji SEKI*2, Kazuho MIKI*2, Takashi FuKIMBARA*2, \\ Hironori KAWAHARA*3 and Hiroshi ITO*4
}

( ${ }^{* 1}$ Department of Food and Nutrition, Faculty of Living Science, Koriyama Womens College: 3-25-2, Kaisei, Koriyama-shi, Fukushima, Japan; ${ }^{* 2}$ Rokko Bio-science Research Laboratory Co., Ltd.: 730-5, Tsurugasone, Yashio-shi, Saitama, Japan; *3Department of Pathology, Tohoku Dental University: 31-1, Sankakudo, Tomotamachi, Koriyama-shi, Fukushima; Japan; ${ }^{* 4}$ Faculty of Animal Science, Kitasato University: 149-2 Maeyachi, Sanbongi, Towada-shi, Aomori, Japan)

In order to clarify the effects of pheophorbide-a, a Chlorella-derived substance with photodynamic activity, the substance was administered orally to rats and on the following day they were irradiated with 20,000 lux of visible light. The toxic effects on these animals were observed, and analysis of blood components and of the resistance of erythrocytes was performed. The results obtained were as follows:

1) Redness was frequently observed on the skin at the auricle and the tail, but scarcely any edema was observed at the occipital and the dorsal positions.

2) $\mathrm{LD}_{50}$ of pheophorbide-a was reduced as the irradiation time with visible light was increased.

3) Toxicity of pheophorbide-a to rats no longer seen by the 4th day after administration, so this substance might be relatively quickly excreted or decomposed.

4) The number of erythrocytes, levels of hemoglobin concentration and hematocrit were increased in the experimental animals. It was also observed that the percentage of rod-shaped nuclear neutrophilic leukocytes in the leukocyte population increased $(p<0.05)$ and that of lymphocytes decreased significantly $(\mathrm{p}<0.05)$.

5) Among serum electrolytes, no significant differences in the levels of calcium and inorganic phosphorus were recognized between the animals of the experimental group and the control group. However, the sodium level of the experimental group showed a significant decrease and the potassium level showed a marked increase as compared with those of the control group.

6) There were no significant differences in serum bilirubin content, serum protein fractions and lipoperoxidase level between these two groups.

7) Among serum enzymes, no differences in the levels of GOT, GPT, LDH and Al-P

*1 郡山女子大学: 福島県郡山市開成 3-25-2

*2 (株) 鹿光生物科学研究所: 埼玉県八潮市鶴々會根 $730-5$
*3 東北歯科大学: 福島県郡山市富田町字三角堂 31-1

*4 北里大学獣医畜産学部: 青森県十和田市大字三本木 字前谷地 149-2 
were found between these groups, but the level of CPK of the experimental group was markedly increased compared with that of the control group.

8) No difference of mean corpuscular fragility of erythrocytes was recognized between these two groups.

(Received May 10, 1982)

Key words: フェオホルバイド a pheophorbide-a; ラット rat; 光力学作用 photodynamic action; 血液成分 blood components; 半数致死量 $\mathrm{LD}_{50}$; 赤血球膜抵抗性 corpuscular osmotic fragility

\section{緒喜}

クロロフィル関連物質で，食餌性の光過敏症の原因物 質*5として挙げられているものは，我が国ではアワビの 内臓中のピロフェオホルバイド $\mathrm{a}^{1)}$ 及び高菜漬のフェオ ホルバイド $\mathrm{a}^{2)}$ があり, 諸外国では牧草中のフェオホル バイド $\mathrm{a}^{3)}$ が知られている.

クロレラの光過敏症の原因物質*5 (田村ら ${ }^{4)}$, 天野ら ${ }^{5)}$ 及び真野ら林により，フェオホルバイド a であることが 報告されている.

又遠藤ら*7 によりアルコール処理したクロレラより， 10-ハイドロキシフェオホルバイド a と同定される光力 学的物質*5が分離されている.

最近天野ら ${ }^{5)}$ は, 高菜漬で今までフェオホルバイド $a$ として取扱れていた物質は，ピロフェオホルバイド、で あることを確認し, 又, 三木ら ${ }^{6)}$ も両物質を純粋に取り 出し,クロレラの光毒性を示す物質*5 はフェオホルバイ ド aであり，高菜漬のそれはピロフェオホルバイド a で あることを確かめた。

昭和 52 年, 市販のクロレラを比較的大量摂取した人 が，直接日光に照射されると，皮䖉炎が発生することが 報告》さされた，又，松浦ら ${ }^{8)}$ は，ラットに高菜漬の粉末 を投与し，これに光照射すると，皮膚に紅斑や浮腫，局 所の脱毛，耳介及び背部の壊死を引き起こし，ときに致 死するもののあることを認め，これは漬物中に含まれる クロロフィル誘導体によることを明らかにした，又，礒 部ら 9) はこの際の動物の死亡原因は, 赤血球膜の脆弱化 が起こり, そのため赤血球内のカリウムが溶出し, これ が心臓の刺激伝導系に作用することによると推察してい る.

本研究ではクロレラより抽出されたクロロフィル誘導 体の 1 つであるフェオホルバイドaをラットに投与し， その後光照射することによって生ずる外観的症状，致死 量及び残存活性, 並びに血球数, 血液像, 血清成分及び

*5これらの文献に用いられた語は同義語でなければな らないが，多少疑義があるので，本稿では，以降光 力学的活性物質の語を用いる。

*6 真野覚, 松浦栄一, 関 洋二, 冨金原孝: 昭和 53 年. 日本農芸化学大会講演要旨, p. 394 (1978)

*7 遠藤 寛, 市岡 稔, 小山隆子：昭和 55 年度日本 農芸化学大会講演要旨集，p. 81 (1979)
赤血球膜の抵抗性の変化について検索した.

\section{実験材料及び実験方法}

1. 実験材料

1) ラット

購入時 6 週令（体重 80 ～100 g） のドンリュウ系雄ラ ットを，ラット用固型飼料（日本クレア(株)製, CE-2) で 3 日間, 恒温恒湿（温度 $25 \pm 2^{\circ}$, 湿度 $50 \pm 5 \%$ ) の部 屋で飼育観察した後, 実験に供した。

2) 飼料

供試した基礎飼料の組成は，小麦デンプン $70 \%$ ，ミル クカゼイン $20 \%$, 大豆油 $5 \%$, 混合塩 $4 \%$ 及びビタ ミ ン末 $1 \%$ で, 等量の熱湯で固型にして給与した。

3)フェオホルバイド a

混合培養法で生産されたクロレラの熱風乾燥粉末（台 湾産）約 $50 \mathrm{~g}$ をとり,これに $70 \%$ アセトン約 $40 \mathrm{ml}$ を加えて, 一夜暗所で室温 $\left(20 \sim 25^{\circ}\right.$ 冬期はサーモスタ ット内）で，クロロフィル関連物質の抽出を行った。こ れを G4 のガラスフィルターでろ過し, 残椬はアセトン で洗いアセトン抽出液を得た。これに同量のエチルエー テルを加えて, 色素をェチルェーテルに移行させ, 上層 のエーテル層をとり，これを濃度の異なる塩酸（1.8 及 び 15\%) で分画抽出し，15\% 塩酸区分を分取し, 同量 のクロロホルムを加えて激しく振とうし，しばらく放置 して 15\% 塩酸区分をクロロホルムに転溶させた。これ をエバポレーターで減圧濃縮してクロロホルムを除き， 濃縮物が溶けるまでアセトンを加えた後, エバポレータ 一で減圧してアセトンをとばし，更に前記同様アセトン を加えた. その中に約 3 倍量のヘキサンを加え，これを 冷蔵庫内に放置して結晶化を計り, 折出した結晶をへキ サンで洗いながら吸引ろ過し，フェオホルバイドaの結 晶を得た.

この結晶はほとんぞ純粋に近いが，微量のクロロフィ ライド，ピロフェオホルバイド a などを含むので, この 量の多いものは, 再精製した. このようにして, 試験材 料には夾雑物が可及的に微量のものを用いた（なお，こ こで用いたフェオホルバイド a は, 鹿光生物科学研究所 で精製したものである).

\section{2. 光照射装置}

光照射装置は Hashimoto ${ }^{10)}$ の使用したものと同一装 䈯を使用した。すなわち, $200 \mathrm{~W}$ タングステンランプ 8 
個を光源とし，途中に熱線と紫外線を遮断するためガラ ス製の水槽（水深 $2 \mathrm{~cm}$ ) を設け，常に水道水を流し，照 度を 20,000 lux に調整（光電池照度計 SPI 5 型，東芝 (株)製）し，照射した。

\section{3. 実験方法}

1) 一般症状の観察

飼料 $5 \mathrm{~g}$ を科量し，同量の熱水を加えて固型にし，そ の飼料にフェオホルバイド a $16 \mathrm{mg}$ を加え光照射前日 の夕方経口投与し (自由摂取)，翌日 15 時間後に 1 時間 照射して，照射中の外観的症状を観察した。

\section{2) 致死量の測定}

基礎飼料を 1 匹 1 日当たり $5 \mathrm{~g}$ とし，同量の熱水を加 えて固型にした. 飼料 $5 \mathrm{~g}$ にフェオホルバイド a を公比 1.5 で 2.00, 3.00, 4.50, 6.70, 10.00, 15.00, 22.50, $33.75,50.63 ， 75.99 \mathrm{mg}$ を添加した 10 種の飼料を作 り，それぞれ 15 匹のラットに光照射前日の夕方投与し， きれいに㩒取したことを確認した. 15 時間後照射を行 い, 1，2，3，4，5 時間照射時に打ける死亡率を求め,

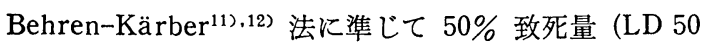
$\mathrm{mg} / 5 \mathrm{~g}$ diet/rat) を算定した.

3) 残存活性

$5 \mathrm{~g}$ 中にフェオホルバイド a $22 \mathrm{mg}$ を含む飼料を光照 射前日の夕方投与し，その 15 時間後 (group 1)，2 日 目 (group 2), 3 日目 (group 3), 4 日目 (group 4), 5 日目（group 5) に各々光照射を 5 時間行った. 光照 射後生存していたラットは, 市販飼料 CE-2 を自由摄取 させ, 恒温恒湿（温度 $25 \pm 2^{\circ}$, 湿度 $50 \pm 5 \%$ ) の部屋で 10 日間飼育し, その健康状態を観察した。

4）血液性状及び血液像

光照射前日の夕方対照群ラット 15 匹に基礎飼料 1 匹 当たり $5 \mathrm{~g}$ を，実験群ラット 30 匹に 1 匹当たりフェオ ホルバイド a $16 \mathrm{mg}$ 添加飼料 $5 \mathrm{~g}$ を投与し, 15 時間後 照射を 1 時間行った. 照射 1 時間後生存ラットを断頭 し，放出する血液を採取しへパリン処理後，500 倍， 5000 倍に希釈 (東亜自動希釈器 HD 683, 東亜医用電子 （株) 製）し，赤血球数，白血球数，ヘマトクリット值は Coulter Counter ZF 型 (Coulter Electronics Inc.), 総 ヘモグロビン濃度は Coulter Hemoglobinometer (Coulter Electronics Inc.) で測定した. 又, これらの值に 基づき赤血球恒数, $\mathrm{MCH}, \mathrm{MCV}, \mathrm{MCHC}^{13)}$ を求めた。

血液像は塗抹標本を gimsa 染色し, 光学顕微鏡で赤 血球形態, 白血球形態を観察し，その数を百分率で表わ した.

5）血清中の電解質，ビリルビン，タンパク分画，過 酸化脂質, 酵素活性

光照射前日の夕方実験群ラットにフェオホルバイド a $16 \mathrm{mg}$ を基礎飼料 $5 \mathrm{~g}$ に添加したものを，対照群には基 礎飼料 $5 \mathrm{~g}$ を投与した. 電解質, ビリルビン，タンパク 分画，過酸化脂質及び酵素活性の測定にはそれぞれ 30 ,
28，30，45 及び 32 匹のラットを用い，刘照群には 15 匹を用いた. 15 時間後 1 時間光照射し, 直ちに生存ラッ トの血液を断頭採取し，血清を分離した．血清中のナト リウム, カリウムは炎光分析法, 塩素はクロライドメー ター法4),カルシウムは 0-cresolphthalein complexone (ocpc) 法 ${ }^{15)}$, 無機リンは Fiske-Subbarou 法, ビリル ビンは Evelyn-Malloy 法 ${ }^{16)} て ゙$ 測定した.

タンパク分画値はセルロース・アセテート膜を用いる 電気泳動法でタンパクを分離し，デンシトメーター（常 光産業(株)）で測定した.

過酸化脂質 (lipoperoxide) は, Yagi 法 ${ }^{17) * * 8}$ で測定 した。

Glutamic oxaloacetic transaminase (GOT), glutamic pyruvate transaminase (GPT) 活性值は Reitman-Frankel 法 $^{18)}$, lactic dehydrogenase (LDH) 活 性值は tetrazolium 法 ${ }^{19)}$, alkaliphosphatase (A1-P) 活性值は Kind-King 法 ${ }^{20)}$, creatine phosphokinase $(\mathrm{CPK})$ 活性值は Formazan 比色法 ${ }^{21)}$ でそれぞれ测定し た.

6）赤血球膜浸透圧脆弱性試験

実験方法 5) と同一条件で 25 匹のラットに光照射 1 時間後, 生存ラットを断頭し放出する血液を採取しへパ リン処理後, 赤血球膜浸透圧脆弱性試験をParpart 法22)で測定した.

\section{実 験 結 果}

\section{1. 一般 症 状}

照射開始後 5〜10 分以内に耳介を前肢でこすり，呼吸 が荒くなり，流延，立毛，震えや四肢のけいれんが見ら れ，奇声を発したり，ケージの中を飛び上がったりする のが見られた．その他に耳介及び尾に紅斑の出現が全例 見られた。

\section{2. $50 \%$ 致死量 $\left(\mathbf{L D}_{50}\right)$}

結果は Table 1 に示すように $\mathrm{LD}_{50}(\mathrm{mg} / 5 \mathrm{~g}$ diet/ rat）は, 照射 1 時間目で $60.48 \mathrm{mg}, 2$ 時間目 15.96 $\mathrm{mg}, 3$ 時間目 $11.58 \mathrm{mg}, 4$ 時間目 $10.21 \mathrm{mg}, 5$ 時間目 $8.05 \mathrm{mg}$ であった．照射時間の経過とともに $\mathrm{LD}_{50}$ 值は 低下したが，その程度は 1 時間值と 2 時間值において著 明で, 約 $1 / 4$ の值となった. 2 時間以降 5 時間までの值 の低下は緩慢であった (Table 1).

\section{3. 残存活性}

結果は Table 2 に示すように投与の翌日（15 時間後） では全例死亡， 2 日目は 5 匹中 3 匹死亡， 3 日目は死亡 例は認められなかったが，耳介及び尾の紅斑が 5 匹中 2 匹に認められた，4日目，5日目では耳介及び尾の紅斑 等認められなかった. 生存したラットは10 日間の観察 で, 皮膚の脱毛, 耳介の壊死等を示さなかった（Table 2).

*8 和光過酸化脂質測定用キット説明書：和光純薬工業 (株) 
Table 1. Effects of Visible Ray on $50 \%$ Lethal Dose of Rat Fed with the Diet Containing Various Doses of Pheophorbide-a

\begin{tabular}{ccrrrrr}
\hline \multirow{2}{*}{$\mathrm{mg} / 5 \mathrm{~g}$ diet/rat } & $\mathrm{n}$ & \multicolumn{5}{c}{ Irradiation time } \\
\cline { 3 - 7 } & & $1 \mathrm{hr}$ & $2 \mathrm{hr}$ & $3 \mathrm{hr}$ & $4 \mathrm{hr}$ & $5 \mathrm{hr}$ \\
\hline 0 (control) & 15 & $0 / 15$ & $0 / 15$ & $0 / 15$ & $0 / 15$ & $0 / 15$ \\
2.00 & 15 & $0 / 15$ & $0 / 15$ & $0 / 15$ & $0 / 15$ & $0 / 15$ \\
3.00 & 15 & $0 / 15$ & $0 / 15$ & $0 / 15$ & $0 / 15$ & $0 / 15$ \\
4.50 & 15 & $0 / 15$ & $0 / 15$ & $2 / 15$ & $4 / 15$ & $6 / 15$ \\
6.70 & 15 & $0 / 15$ & $2 / 15$ & $6 / 15$ & $10 / 15$ & $12 / 15$ \\
10.00 & 15 & $0 / 15$ & $2 / 15$ & $6 / 15$ & $9 / 15$ & $10 / 15$ \\
15.00 & 15 & $0 / 15$ & $6 / 15$ & $10 / 15$ & $12 / 15$ & $12 / 15$ \\
22.50 & 15 & $3 / 15$ & $14 / 15$ & $15 / 15$ & $15 / 15$ & $15 / 15$ \\
33.75 & 15 & $1 / 15$ & $15 / 15$ & $15 / 15$ & $15 / 15$ & $15 / 15$ \\
50.63 & 15 & $1 / 15$ & $15 / 15$ & $15 / 15$ & $15 / 15$ & $15 / 15$ \\
75.95 & 15 & $12 / 15$ & $15 / 15$ & $15 / 15$ & $15 / 15$ & $15 / 15$ \\
$\mathrm{LD}_{50}$ & & 60.48 & 15.96 & 11.58 & 10.81 & 8.05 \\
\hline
\end{tabular}

Table 2. Toxic Responses on Rat Irradiated at Various Day after the Administration of Pheophorbide-a

\begin{tabular}{|c|c|c|c|c|}
\hline $\begin{array}{c}\text { Day after } \\
\text { administration } \\
\text { of Pheophorbide-a }\end{array}$ & $\begin{array}{l}\text { Body-weight } \\
(\mathrm{g})\end{array}$ & Erythema & Death & $\begin{array}{l}\text { Survival time } \\
\text { (hour: } \mathrm{min} \text { ) }\end{array}$ \\
\hline \multirow[t]{5}{*}{1} & 79 & + & + & $1: 10$ \\
\hline & 77 & + & + & $1: 11$ \\
\hline & 84 & + & + & $1: 03$ \\
\hline & 92 & + & + & $3: 00$ \\
\hline & 93 & + & + & $1: 40$ \\
\hline \multirow[t]{5}{*}{2} & 92 & + & + & $2: 11$ \\
\hline & 112 & + & - & \\
\hline & 110 & + & + & 1.50 \\
\hline & 94 & + & + & $3: 19$ \\
\hline & 109 & + & - & \\
\hline \multirow[t]{5}{*}{3} & 102 & + & - & \\
\hline & 116 & + & - & \\
\hline & 110 & - & - & \\
\hline & 115 & - & - & \\
\hline & 122 & - & - & \\
\hline \multirow[t]{5}{*}{4} & 119 & - & - & \\
\hline & 125 & - & - & \\
\hline & 132 & - & - & \\
\hline & 132 & - & - & \\
\hline & 131 & - & - & \\
\hline \multirow[t]{5}{*}{5} & 114 & - & - & \\
\hline & 123 & - & - & \\
\hline & 119 & - & - & \\
\hline & 127 & - & - & \\
\hline & 123 & - & - & \\
\hline
\end{tabular}

Pheophorbide-a $(22 \mathrm{mg}$ ) was fed with diet to all animals and on the following day they were irradiated with 20,000 lux for 1 hour. 
Table 3. Effects of Visible Ray on Blood Components of Rats Fed with a Diet Containing Pheophorbide-a

\begin{tabular}{|c|c|c|}
\hline \multirow[b]{2}{*}{ Diet } & \multicolumn{2}{|r|}{ Group } \\
\hline & $1 \underset{\text { Basal }}{(n=15)}$ & $\begin{array}{c}2(\mathrm{n}=17) \\
\text { Basal+ } \\
\text { Pheophorbide-a } \\
16 \mathrm{mg}\end{array}$ \\
\hline $\begin{array}{l}\text { Erythrocyte } \\
\qquad\left(\times 10^{4} / \mathrm{mm}^{3}\right)\end{array}$ & $773 \pm 12^{*}$ & $\left.845 \pm 27^{a}\right)$ \\
\hline Hemoglobin (g/dl) & $14.5 \pm 0.2$ & $16.0 \pm 0.5^{b)}$ \\
\hline Hematocrit $(\%)$ & $50 \pm 1$ & $54 \pm 2^{\text {a })}$ \\
\hline $\mathrm{MCH}(\mu \mu \mathrm{g})$ & $18.7 \pm 0.3$ & $19.1 \pm 0.3$ \\
\hline $\operatorname{MCV}\left(\left(\mu^{3}\right)\right.$ & $64.5 \pm 1.2$ & $63.4 \pm 1.2$ \\
\hline $\mathrm{MCHC}(\%)$ & $29.3 \pm 0.3$ & $30.0 \pm 0.4$ \\
\hline $\begin{array}{l}\text { Leukocyte } \\
\qquad\left(\times 10^{2} / \mathrm{mm}\right)\end{array}$ & $7973 \pm 692$ & $8776 \pm 724$ \\
\hline Meta. (\%) & $0 \pm 0$ & $0 \pm 0$ \\
\hline Stab. & $3 \pm 0$ & $4 \pm 1$ \\
\hline Segment. & $26 \pm 3$ & $\left.34 \pm 2^{a}\right)$ \\
\hline Lympho. & $67 \pm 3$ & $58 \pm 2^{\text {a })}$ \\
\hline Mono. & $4 \pm 0$ & $4 \pm 0$ \\
\hline Eosino. & $0 \pm 0$ & $0 \pm 0$ \\
\hline Baso. & $0 \pm 0$ & $0 \pm 0$ \\
\hline
\end{tabular}

Pheophorbide-a (16 mg) was admistered oral. ly to all animals and on the following day they were irradiated with 20,000 lux for 1 hour.

* Mean \pm S.E.

a) Significant difference $(p<0.05)$ against Group 1

b) Significant difference $(p<0.01)$ against Group 1

\section{4. 赤血球数, ヘモグロビン漕度, ヘマトクリット値, 赤血球恒数, 白血球数, 白血球百分率}

照射中にラット 30 匹のうち 13 匹が死亡した. 照射 1 時間終了後の生存ラット 17 匹の赤血球を対照群 15 匹のそれと比較すると, Table 3 に示すように, 赤血球 数 $(p<0.05)$, ヘマトクリット值 $(p<0.05)$, へモグロ ビン濃度（ $p<0.01 ）$ は有意に増加した. しかし, Wintrobe の赤血球恒数 $(\mathrm{MCH}, \mathrm{MCV}, \mathrm{MCHC})$ に变動は 認められなかった (Table 3).

白血球数は両群間に差は認められなかったが，その組 成のらち分葉核好中球が有意に増加し $(p<0.05)$, 一方 リンパ球は有意に減少 $(p<0.05)$ した。

\section{5. 血清成分 \\ 1) 電解質}

照射終了後直ちに生存 17 匹を検査したところ， Table 4 に示すようにナトリウムは対照群に対し有意に減 少し $(\mathrm{p}<0.05)$, カリウムは反対に増加した. その他, 無機リン, カルシウム及び塩素は対照群との間に有意差 は認められなかった。

2) ビリルビン
Table 4. Effects of Visible Ray on Serum Constituents of Rats Fed with a Diet Containing Pheophorbide-a

\begin{tabular}{|c|c|c|}
\hline \multirow[b]{2}{*}{ Diet } & \multicolumn{2}{|c|}{ Group } \\
\hline & $\begin{array}{c}1 \\
\text { Basal }\end{array}$ & $\begin{array}{c}2 \\
\text { Basal+ } \\
\text { Pheophorbide-a } \\
16 \mathrm{mg}\end{array}$ \\
\hline \multicolumn{3}{|l|}{ Electrolytes } \\
\hline $\mathrm{Na}(\mathrm{mEq} / \mathrm{L})$ & 148. $0 \pm 0.8^{*}$ & $143.2 \pm 0.9^{a)}$ \\
\hline $\mathrm{K}(\mathrm{mEq} / \mathrm{L})$ & $7.5 \pm 0.2$ & $9.2 \pm 0.4^{\mathrm{a})}$ \\
\hline $\mathrm{Ca}(\mathrm{mEq} / \mathrm{L})$ & $5.1 \pm 0.1$ & $5.1 \pm 0.1$ \\
\hline $\mathrm{Cl}(\mathrm{mg} / \mathrm{dl})$ & $101.8 \pm 0.6$ & $100.6 \pm 0.5$ \\
\hline $\mathrm{P}(\mathrm{mg} / \mathrm{dl})$ & $15.7 \pm 0.7$ & $15.8 \pm 0.8$ \\
\hline $\begin{array}{l}\text { Total-bilirubin } \\
\text { (mg/dl) }\end{array}$ & $0.90 \pm 0.18$ & $0.95 \pm 0.15$ \\
\hline Direct-bilirubin & $0.47 \pm 0.11$ & $0.58 \pm 0.10$ \\
\hline Indirect-bilirubin & $0.43 \pm 0.08$ & $0.38 \pm 0.07$ \\
\hline $\begin{array}{l}\text { Total-protein } \\
\text { (g/dl) }\end{array}$ & $6.3 \pm 0.1$ & $6.6 \pm 0.3$ \\
\hline A/G (ratio) & $2.4 \pm 0.1$ & $2.4 \pm 0.1$ \\
\hline Albumin $(\%)$ & $70.0 \pm 0.7$ & $70.2 \pm 0.7$ \\
\hline$\alpha_{1}$-Globulin $(\%)$ & $10.2 \pm 0.4$ & $11.3 \pm 0.3$ \\
\hline$\alpha_{2}$-Globulin $(\%)$ & $5.5 \pm 0.2$ & $5.2 \pm 0.3$ \\
\hline$\beta$-Globulin $(\%)$ & $11.3 \pm 0.4$ & $11.4 \pm 0.4$ \\
\hline$\gamma$-Globulin $(\%)$ & $2.9 \pm 0.5$ & $1.4 \pm 0.3$ \\
\hline $\begin{array}{l}\text { Lipoperoxide } \\
\qquad(\mathrm{nmol} / \mathrm{ml})\end{array}$ & $10.05 \pm 0.6$ & $10.04 \pm 0.8$ \\
\hline \multicolumn{3}{|l|}{ Serum enzymes } \\
\hline GOT (KU) & $200 \pm 7$ & $230 \pm 14$ \\
\hline GPT (KU) & $23 \pm 3$ & $24 \pm 2$ \\
\hline $\mathrm{Al} \cdot \mathrm{P}(\mathrm{U})$ & $27 \pm 3$ & $25 \pm 3$ \\
\hline LDH (WU) & $609 \pm 54$ & $771 \pm 79$ \\
\hline CPK (IU/1) & $235 \pm 2$ & $280 \pm 17^{a)}$ \\
\hline
\end{tabular}

See Tables 2 and 3.

Group 1: $\mathrm{n}=15$

Group 2: electrolytes, $n=17$; bilirubin, $n=14$; protein, $n=16$; lipoperoxide, $n=24$; enzymes, $\mathrm{n}=15$

生存した 14 匹を検査した結果は Table 4 に示すよう に各ビリルビン濃度は, 対照群のそれと有意差は認めら れなかった.

3) タンパク分画

生存 16 匹を検査した結果は Table 4 に示すように, 総タンパク量, アルブミン, グロブリンはいずれも対照 群との間に有意差は認められなかった。

4）過酸化脂質

生存 24 匹を検査した結果は Table 4 に示すように, 対照群との間に有意差はなかった。

5）酵素活性

生存 15 匹を検査した結果は Table 4 に示すように, 
Table 5. Effects of Visible Ray on the Osmotic Fragility (MCF) of Erythrocyte of Rat Fed with a Diet Containing Pheophorbide-a

\begin{tabular}{ccc}
\hline & \multicolumn{2}{c}{ Group } \\
\cline { 2 - 3 } Diet & $1 \begin{array}{c}(\mathrm{n}=15) \\
\text { Basal }\end{array}$ & $\begin{array}{c}2(\mathrm{n}=15) \\
\text { Basal }\end{array}$ \\
& & $\begin{array}{c}\text { Pheophorbide-a } \\
16 \mathrm{mg}\end{array}$ \\
\hline Salt solution $\%$ & & \\
0.85 & $1.99 \pm 0.80^{*}$ & $0.34 \pm 0.16$ \\
0.80 & $0.24 \pm 0.12$ & $0.17 \pm 0.11$ \\
0.75 & $0.33 \pm 0.12$ & $0.52 \pm 0.11$ \\
0.70 & $0.53 \pm 0.10$ & $0.76 \pm 0.14$ \\
0.65 & $0.84 \pm 0.18$ & $0.82 \pm 0.12$ \\
0.60 & $0.65 \pm 0.14$ & $0.75 \pm 0.11$ \\
0.55 & $0.83 \pm 0.20$ & $0.87 \pm 0.13$ \\
0.50 & $1.07 \pm 0.17$ & $1.66 \pm 0.23$ \\
0.45 & $5.54 \pm 1.25$ & $7.77 \pm 1.68$ \\
0.40 & $30.71 \pm 14.76$ & $32.77 \pm 14.59$ \\
0.35 & $70.00 \pm 14.02$ & $79.12 \pm 14.59$ \\
0.30 & $90.63 \pm 1.72$ & $93.29 \pm 12.69$ \\
0.20 & $97.85 \pm 1.31$ & $98.01 \pm 1.48$ \\
0.10 & $97.76 \pm 0.02$ & $99.68 \pm 1.64$ \\
Salt solution (\%) & $0.38 \pm 0.02$ & $0.38 \pm 0.02$ \\
at $50 \%$ hemolysis & & \\
\hline See & & \\
\hline
\end{tabular}

See Tables 2 and 3.

$\mathrm{CPK}$ 活性值は対照群に対し有意に増加（p<0.05）した が，その他の酵素活性值には差がなかった。

\section{6. 赤血球膜浸透圧脆弱性試験}

照射終了後直ちに生存ラット 15 匹を検查した結果は Table 5 に示すように, 対照群と同様の結果を示し, 50 $\%$ 溶血度すなわち平均赤血球脆弱性 (mean corpuscular fragility: MCF) に差はなかった.

考察

光力学的活性物質はいろいろ知られているが, 食品中 に含まれるクロロフィルの分解物 ${ }^{10)}$ その 1 つである.

高菜漬に含まれるピロフェオホルバイド $\mathrm{a}$ の光力学的 活性については，ラットを用いた実験により詳しく報告 した8). 今回はクロレラより抽出したフェオホルバイド a を用い同様の実験を行い, 両者における光力学的作用 を比較した。

フェオホルバイド aをラットに経口投与後光照射する と, ピロフェオホルバイド a と同様, 耳介, 尾部の発赤, 耳介を前肢でこする動作を示した. すなわち，両者にお ける外観的症状はよく似た点があるが，細部には相違が あり, 高菜漬投与群は後頭部の浮腫, 後頭部, 耳介及び 背部の潰瘍形成, 壊死が認められたが，フェオホルバイ ドの投与群はそれらが認められなかった。

$\mathrm{LD}_{50}$ 値 $(\mathrm{mg} / 5 \mathrm{~g} \mathrm{diet} / \mathrm{rat})$ は投与量と照射時間に依
存し，1 時間照射時の $\mathrm{LD}_{50}$ は，2 時間照射の約 4 倍の 值を示した. しかし，その後の照射時間による $L_{50}$ 伯 は急変することなく緩やかに低下した。 よって，フェオ ホルバイド a の光力学的活性は, 照射開始後比較的短時 間内に発現し，生体に著しい影響を与えていることが推 察される.

フェオホルバイド $\mathrm{a}$ の投与後の光力学的活性は, 急速 に低下し，投与後 2 日目の照射では， 5 匹中 3 匹死亡し たが，3日目の照射では死亡例はなく，紅斑が 5 匹中 2 匹認められたのみであった.このラットを更に 10 日間， 市販ラット飼料で飼育し，観察したが，高菜漬投与でほ とんどのラットに見られた皮㲊の脱毛，耳介の壊死は観 察されなかった.この両者の間の差は総タンパク, アル ブミンの変化であり, 浮腫発現及び皮覤の脱毛, 耳介の 買死の有無であると思われる。

血液性状の変化は，フェオホルバイドaを投与し，光 照射を行うと, 赤血球数, ヘマトクリット, ヘモグロビ ンは有意に増加した. 一方, 高菜漬で生ずる光力学的作 用は, 白血球, へモグロビンはあまり変化なく, 赤血球 ヘマトクリットは有意に減少することが観察されてい $ろ^{23)}$. 礒部 ${ }^{26)}$ の報告でも, 野沢菜漬投与の光力学的作 用で溶血が起こるのを認めているが，今回のフェオホル バイド $\mathrm{a}$ 投与ラットの血液所見は, 貧血状態は認められ ず，むしろ赤血球増多の傾向を示したことは興味深い。

白血球像は，フェオホルバイド a 投与群は白血球中の 分葉核好中球が有意に増加し，リンパ球は有意に減少し た。

血清電解質のうち, ナトリウムが有意に減少し, カリ ウムが有意に増加したが, その他の電解質は, 対照群と の間に差がなかった. 高菜漬 (ピロフェオホルバイドa) 投与の光力学的作用発現ラットでは, 血清カリウムの増 加が報告されているが8)，この際のカリウムの増加は， 赤血球の溶血によると考えられている. 又, 礒部ら ${ }^{9)}$ は この血清高カリウムの原因は, 赤血球膜の脆弱化により 赤血球内のカリウムが血清に溶出するためであろうと述 べている.

本実験の血液は溶血が起こったとみられる所見はなか った. 赤血球内のカリウムの溶出の有無については, 赤 血球内カリウムを検討する必要があろう.

血清ビリルビンの各分画はいずれも正常範 囲 ${ }^{24)} に あ$ り，対照群との間に有意差はなかった。ビリルビンが血 清中に増加するのは, 赤血球が大量に破壊され, 血清中 に遊離ビリルビンが放出されるためである．この点から も溶血が起こったとは考えられない.

血清タンパク分画值中, 高菜漬投与の光力学的作用発 現ラットは, 総タンパク，アルブミンの減少が報告され ているが，これはアルブミンが血清から組織に浸出する ためと推察され8)，このため浮腫が生ずると考えられ る. しかし, 本実験の血清タンパク分画值は対照群との 
間に差は認められなかった。

又, 高菜漬による実験で, 血清過酸化脂質が, 対照群 に対して有意に増加することが報告されているが8)，木 村ら ${ }^{25)}$ も同様の結果を認めて打り, これはピロフェオホ ルバイド a の光力学的作用により, 赤血球膜に過酸化酵 素が生成され，膜内脂質を過酸化したためと推察してい る. 更にその結果, 溶血が起こると述べている. しかし， 本実験の過酸化脂質は増加が見られず，対照群との間に は差がなかった. クロレラ由来のフェオホルバイド $\mathrm{a}$ と 高菜漬由来のピロフェオホルバイド $\mathrm{a}$ の赤血球膜に対す る作用が異なるものと思われる.

血清酵素の GOT, GPT, LDH 及び Al-P 活性值は, 対照群との間に有意差はなかったが， CPK 活性值は有 意に増加した. これに対し，高菜漬の実験はGOT, GPT, LDH 活性値の有意な増加が報告され，これは心 筋, 骨格筋などに障害を受けているものと推察されてい $る^{8)}$. 礒部ら ${ }^{26)}$ も同様の結果を報告しておう, 酵素活性 值の増加は, 細胞膜の脆弱化が起こり, 細胞内液の漏出 をきたし, 血清中の酵素活性值の増加が起こると考えら れている. 本実験は CPK 活性值が増加したが，この酵 素は骨格筋や心筋などに多く存在するので, クロレラ由 来フェオホルバイド a は，これらの臓器に何らかの影響 を与えているのかも知れない。

赤血球膜浸透俚脆弱性試験は，対照群との間に差はな く, 赤血球膜の脆弱化は認められなかった.

\section{要 約}

クロレラより抽出したフェオホルバイドaをラットに 投与し，可視光線照射による影響を検討した。

1. 光照射後直ちに耳介を前肢でこすり, 又ヶージの 中を激しく動きまわり，15～30 分後に耳介及び尾部の 発赤を生じた。

2. 投与量と照射時間に依存した致死がみられた。

3. 残存活性は投与後 3 日程度認められた。

4. 照射 1 時間終了後の生存ラットの血液所見は, 赤 血球, ヘモグロビン, ヘマトクリットが共に増加し，血 液像は分葉核好中球が増加し, リンパ球が減少した.

5. 血清電解質のうち塩素, カルシウム, 無機リンの 含有量には変化はなかったが，ナトリウムは有意に減少 し，カリウムは有意に増加した.

6. 血清ビリルビンには変化はみられなかった

7. 血清タンパク分画值及び過酸化脂質值に变化は認 められなかった。

8. 血清酵素活性值のうち GOT, GPT, LDH, 及び A1-P 活性值には変化なく, CPK 活性值は有意に増加し た.

9. 赤血球膜浸透生脆弱性に変化は認められなかっ た。

\section{謝 辞}

本報告の発表の許可を与えられた鹿光生物科学研究所
社長, 鹿野光雄氏に深く感謝の意を表します。

又，検査分析の御指導を賜わりました郡山臨床検查セ ンタ一所長，高橋 傑氏，主任技師，大内恵子氏に深く 感謝の意を表します。

最後に御校閲, 御指導を賜わりました北里大学衛生学 部, 安斎 博教授に深く感謝の意を表します.

文献

1）橋本芳郎，堤 淳三：食衛誌，4，185～191 (1963).

2）山田幸二，中村延蔵：栄養と食糧，25，466４71 (1972).

3) Lohrey, E., Topper, B., Heve, E. L.: Br. J. Nutr., 31, 159 166 (1974).

4) 田村行弘, 直木俊夫, 嶋村保洋, 西垣 進, 直井 家壽太：食衛誌. 20, 173～180 (1979).

5) 天野立爾, 池 慶子, 内山 充: 食品衛生研究, 28, 739 745 (1978).

6）三木和保, 田島 修, 松浦栄一, 山田幸二, 冨金 原孝：農化. 54, 721～726 (1980).

7) 駒井喜明, 太貫憲一, 山岸 宏, 白島憲行: 食品 衛生研究, 28, 747 752 (1978).

8) 松浦栄一, 平野隆司, 山田幸二, 飯島直子, 河原 裕憲：栄養と食糧，31，459～463 (1976).

9）礒部明彦，佐々木陸郎，木村修一：同上, 30, 99 〜04 (1977).

10) Hashimoto, Y., Tsutsumi, J.: Bull. Japan. Soc., Sci., Fisheries, 27, 850 866 (1961).

11) 高木敬次郎, 小澤 光: 薬物学実験, $179(1976)$. 南山堂

12) Kärber, G.: Arch. Exper. Pathol. and Pharm. akol, 162, 480 487 (1931).

13） 日野志郎：衛生検査技術講座，血液学，107～109 (1970). 医歯薬出版

14）金井 泉, 金井正光: 臨床検査法提要, VII, 33 35 (1971). 金原出版

15）金井 泉, 金井正光：同上, II, 20～26 (1971). 金原出版

16）金井 泉, 金井正光: 同上, XII, 45 46 (1971). 金原出版

17) Yagi, K.: Biochem. Med., 15, 21, 2 (1976).

18) Reitman, S., Frankel, S.: Am. J. Clin. Pathol., 28, 56〜63 (1957).

19) Caband, P. G., Wrobewsski, F.: ibid., 30, 234 $\sim 236$ (1958).

20）奥田 清: 臨床検査, II, (医化学実験法講座) 313, 456 460 (1973). 中山書店

21）金井 泉, 金井正光：臨床検查法提要, VII, 81 $\sim 82$ (1971). 金原出版

22）山木きみよ，三輪史朗：臨床検查, $22,2 \sim 5$ 
(1978).

23）松浦栄一, 青木喜代子, 平野隆司, 山田幸二, 河 原裕憲：栄養と食糧，30，307～311 (1977).

24）長瀬すみ, 田中寿子：実験動物の臨床生化学デー タ, 236 (1976). ソフトサイエンス社
25）木村修一, 臹部明彦, 斎寿 明：ビタミン, 53, 543〜548 (1979).

26）礒部明彦，木村修一：栄養と食糧，29，497～500 (1976) . 